\title{
Towards targeting PD-1/PD-L1 axis in breast cancer, pre-clinical data
}

\author{
Hazem Ghebeh"1* Dilek Colak², Asma Tulbah³ ${ }^{3}$ Abdullah Alsuliman ${ }^{1}$ \\ From Breast Cancer Immunotherapy Symposium (BRECIS), part of the Sidra Symposia Series, held in partner- \\ ship with the Society for Immunotherapy of Cancer \\ Doha, Qatar. 13-14 April 2015
}

PD-L1 is a ligand that upon binding to its receptor (PD-1) on T-cells leads to T-cell anergy/and or apoptosis $[1,2]$. We have shown that PD-L1 is expressed in breast cancer where its expression correlates with estrogen receptor (ER) negativity [3]. To understand the mechanism of the constitutive expression of PD-L1 in tumor cells of ER negative cells we used gene-in and out approach, large scale bioinformatics and immunohistochemistry. We have demonstrated that epithelial to mesenchymal transition (EMT) upregulates PD-L1 expression while cells expressing ER downregulates PD-L1, in parallel with reversal of EMT process. Bioinformatics analysis of gene expression signatures of breast tumors showed a significant correlation between EMT score and PD-L1 mRNA expression. Strikingly, very strong association were found between PD-L1 expression and claudin low breast cancer, a subset of breast cancer known to have high EMT score. In conclusion, we have characterized the expression of PDL1 in breast cancer and we have demonstrated a strong association between PD-L1 expression, EMT status and claudin-Low breast cancer. Our finding will be essential for choosing the appropriate subset of breast cancer patients that will likely benefit from anti-PD-L1 targeted therapy and understand biological changes upon anti-PDL1 therapy.

\footnotetext{
Authors' details

${ }^{1}$ Stem Cell \& Tissue Re-engineering Program, King Faisal Specialist Hospital and \& Research Centre, Takhassusi Road, Al-Maathar, Riyadh, Saudi Arabia. ${ }^{2}$ Department of Biostatistics, Epidemiology and Scientific Computing, King Faisal Specialist Hospital \& Research, Takhassusi Road, Al-Maathar, Riyadh, Saudi Arab. ${ }^{3}$ Department of Pathology and Laboratory Medicine, King Faisal Specialist Hospital \& Research Centre, Riyadh, Saudi Arab.
}

${ }^{1}$ Stem Cell \& Tissue Re-engineering Program, King Faisal Specialist Hospital and \& Research Centre, Takhassusi Road, Al-Maathar, Riyadh, Saudi Arabia Full list of author information is available at the end of the article
Published: 14 August 2015

\section{References}

1. Freeman GJ, Long AJ, Iwai Y, Bourque K, Chernova T, Nishimura H, Fitz LJ, Malenkovich N, Okazaki T, Byrne MC, et al: Engagement of the PD-1 immunoinhibitory receptor by a novel B7 family member leads to negative regulation of lymphocyte activation. J Exp Med 2000, 192(7):1027-1034.

2. Selenko-Gebauer N, Majdic O, Szekeres A, Hofler G, Guthann E, Korthauer U, Zlabinger $\mathrm{G}$, Steinberger $\mathrm{P}$, Pickl WF, Stockinger $\mathrm{H}$, et al: B7-H1 (programmed death-1 ligand) on dendritic cells is involved in the induction and maintenance of T cell anergy. J Immunol 2003, 170(7):3637-3644.

3. Ghebeh H, Mohammed S, Al-Omair A, Qattan A, Lehe C, Al-Qudaihi G, Elkum N, Alshabanah M, Amer Bin S, Tulbah A, et al: The B7-H1 (PD-L1) T lymphocyte-inhibitory molecule is expressed in breast cancer patients with infiltrating ductal carcinoma: correlation with important high-risk prognostic factors. Neoplasia 2006, 8(3):190-198.

doi:10.1186/2051-1426-3-S1-P7

Cite this article as: Ghebeh et al:: Towards targeting PD-1/PD-L1 axis in breast cancer, pre-clinical data. Journal for ImmunoTherapy of Cancer 2015 3(Suppl 1):P7.
Submit your next manuscript to BioMed Central and take full advantage of:

- Convenient online submission

- Thorough peer review

- No space constraints or color figure charges

- Immediate publication on acceptance

- Inclusion in PubMed, CAS, Scopus and Google Scholar

- Research which is freely available for redistribution
() Bïomed Central
C Biomed Central

(c) 2015 Ghebeh et al. This is an Open Access article distributed under the terms of the Creative Commons Attribution License (http:// creativecommons.org/licenses/by/4.0), which permits unrestricted use, distribution, and reproduction in any medium, provided the original work is properly cited. The Creative Commons Public Domain Dedication waiver (http://creativecommons.org/publicdomain/ zero/1.0/) applies to the data made available in this article, unless otherwise stated. 